PRACE GEOGRAFICZNE

zeszyt $149,2017,55-80$

doi: 10.4467/20833113PG.17.010.6926

Instytut Geografii i Gospodarki Przestrzennej UJ

Wydawnictwo Uniwersytetu Jagiellońskiego

\title{
CZYNNIKI WARUNKUJĄCE PREFERENCJE I DZIAŁANIA SAMORZĄDÓW GMINNYCH W POLSCE W ZAKRESIE ŁAGODZENIA I ADAPTACJI DO ZMIAN KLIMATYCZNYCH ${ }^{1}$
}

\author{
Marta Lackowska, Pawet Swianiewic:
}

\section{Factors influencing preferences and actions of Polish municipal authorities regarding mitigation and adaptation to climate change}

Abstract: In the article we analyze types and determinants of local climate policies undertaken by Polish communes. We use a distinction between adaptation and mitigation policies. Our study is based on a survey on all Polish communes conducted in 2014 (response rate 51\%). The research has revealed a far-reaching coherence of situation in Polish and foreign communes (when compared to foreign literature). Polish communes declare most frequently mitigation activities, which we explain by national and EU support. Obligation for local plans of low emission economy, together with financial incentives for this goal has led to a local focus being placed on air quality.

Among the factors explaining differentiation in locally undertaken actions, the most important one is size (population) of a commune (which influences e.g. the competences of local administration). In the case of adaptation, the perceived vulnerability of a commune (experience of past and expectation of future extreme weather events related to water) is also

\footnotetext{
${ }^{1}$ Artykuł opracowany na podstawie badań przeprowadzonych w ramach projektu PolCitClim - Organizing for Resilience. A Comparative Study on Institutional Capacity, Governance, and Climate Change Adaptation in Poland and Norway finansowanego z Funduszy Norweskich w ramach Programu Polsko-Norweska Współpraca Badawcza zarządzanego przez Narodowe Centrum Badań i Rozwoju (umowa nr POL-NOR/201304/75/2013).
} 
important. Other factors, like the affluence of municipality a commune, has turned out to have secondary importance, determined by size. When looking at determinants of the will to spend more money on mitigation than adaptation, we have discovered that it depends on the conviction that human activity influences climate changes and that local governments should undertake climate policies.

Keywords: mitigation and adaptation to climate change, local policies, Poland

Zarys treści: W artykule analizujemy rodzaje działań dotyczących zmian klimatu, jakie podejmują gminy polskie, a także determinanty podejmowanych polityk. Posługujemy się przy tym rozróżnieniem na działania łagodzące zmiany klimatu i adaptacyjne. Materiał empiryczny pochodzi z ankiety przeprowadzonej wśród wszystkich gmin polskich w 2014 r. (zwrot 51\%). Badanie wykazało znaczną zbieżność sytuacji w polskich gminach z tą opisywaną w literaturze zagranicznej. Gminy polskie najczęściej deklarują działania łagodzące zmiany klimatu, co przypisujemy ogólnopolskiemu i unijnemu wsparciu. Wytyczne dotyczące realizacji na poziomie lokalnym gospodarki niskoemisyjnej w połączeniu ze źródłami dofinansowania inwestycji z tego zakresu zaowocowały wyraźnym skupieniem samorządów na ochronie powietrza. Wśród zmiennych wyjaśniających przyczyny zróżnicowania działań wobec zmian klimatu najważniejsza okazała się wielkość samorządu, wiążąca się z jego zasobami (np. kompetencjami pracowników administracyjnych). W przypadku działań adaptacyjnych ważne jest także postrzegane zagrożenie ekstremalnymi zjawiskami pogodowymi związanymi ze środowiskiem wodnym. Pozostałe zmienne (w tym zamożność samorządu) mają charakter wtórny wobec wielkości. Z kolei deklarowanie chęci wydawania większych pieniędzy na łagodzenie niż na adaptację wiąże się wyraźnie $z$ wiarą we wpływ człowieka na zmiany klimatu oraz przekonaniem, że samorząd powinien prowadzić politykę klimatyczną.

Stowa kluczowe: łagodzenie i adaptacja do zmian klimatu, polityki lokalne, Polska

\section{Wstęp}

Ochrona klimatu staje się coraz ważniejszą częścią polityki rozwoju zrównoważonego. Jej znaczenie w skali globalnej jest niekwestionowane, a jednocześnie rośnie rola szczebla lokalnego w realizacji polityk klimatycznych. Można mówić o swoistej glokalizacji, czyli - parafrazując klasyczną definicję Swyngedouwa (2004) - o przesunięciu decyzyjności i sprawstwa w górę i w dół wobec poziomu państwowego.

Rolę samorządów lokalnych w polityce klimatycznej podkreśla wielu autorów (Bulkeley, Kern 2006; Granberg, Elander 2007; Storbjörk 2007; Jackson, Lynch 2011; Shaw, Theobald 2011; Hoppe i in. 2014). Hoppe i in. (2014) wymieniają dwa powody tej istotności: (1) bliskość gmin do mieszkańców i lokalnego biznesu, która sprawia, że samorząd może promować pożądane działania; oraz (2) potencjał transformacyjny wynikający z tego, że wiele lokalnych decyzji ma bezpośrednie przełożenie na stan środowiska przyrodniczego. Ale szukając wyjaśnień wagi lokalności w politykach wobec zmian klimatu, można też znów sparafrazować słowa odnoszone do glokalizacji - wszystkie globalne zjawiska mają swoje lokalne emanacje, zachodzą 
w konkretnych miejscach (lokalnych przestrzeniach) i to one muszą sobie radzić ze skutkami globalnych procesów.

Podkreśla się też, że o ile skuteczne działania łagodzące ${ }^{2}$ wymagają koordynacji w szerszej skali, o tyle adaptację można z powodzeniem realizować w ramach polityki lokalnej, szczególnie że lokalne uwarunkowania determinują specyfikę potrzeb adaptacyjnych.

Odwołując się do tych wątków, w niniejszym artykule staramy się przedstawić główne działania z zakresu polityki klimatycznej podejmowane przez polskie gminy, sprawdzić, w jakim stopniu koncentrują się one na zapobieganiu, a w jakim na adaptacji, oraz poszukać czynników determinujących poziom zainteresowania i podejmowanie lokalnej polityki klimatycznej. Zajmując się politykami samorządowymi, nie podejmujemy w tekście dyskusji nad przyrodniczym wymiarem zmian klimatu.

\section{Podstawowe pojęcia i ewolucja dyskursu}

Badania dotyczące lokalnych reakcji na zmiany klimatu sięgają lat 60. XX w. Ich intensyfikacja towarzyszyła opublikowaniu w 1972 r. raportu Klubu Rzymskiego. Z czasem dyskurs dotyczący obciążenia środowiska przyrodniczego antropopresją ewoluował, a z nim także podstawowa terminologia. Pierwotną ochronę środowiska zajęła pod koniec lat 80. szersza koncepcja rozwoju zrównoważonego, uwzględniająca nie tylko komponent przyrodniczy, ale też jego równowagę z potrzebami rozwoju gospodarczego i społecznego. W połowie lat 90. na czoło wysunął się dyskurs dotyczący zmian klimatu i odpowiadających na nie polityk. Można zatem w pewnym sensie mówić o zawężeniu dyskusji nad rozwojem zrównoważonym do kwestii klimatu. Z koncepcji zmian klimatu wyłoniły się dwa obszary polityk: w pierwszej kolejności zapobieganie tym zmianom czy ich łagodzenie (ang. mitigation), w drugiej-dostosowywanie się doń (ang. adaptation). Szybko zauważono, że podejmowane działania zapobiegające są niewystarczające, by powstrzymać zmiany klimatu (Matczak 2008; Hoppe i in. 2014;). Spowodowało to wzrost istotności adaptacji, czyli dopasowywania się do nieuchronnych zmian w taki sposób, by ograniczać negatywne skutki tych zmian dla działalności ludzkiej (por. Verchot i in. 2007).

\footnotetext{
${ }^{2} \mathrm{~W}$ literaturze polskiej zaczął zadomawiać się termin będący kalką językową angielskiego określenia mitigation (łagodzenie, od ang. to mitigate - łagodzić). Uwzględniając zupełnie inne znaczenie czasownika polskiego (mitygować - hamować czyjąś zapalczywość, przywoływać do porządku wobec niestosownego zachowania) staramy się unikać niefortunnego terminu mitygacja i zastępować go słowami lepiej oddającymi sedno zjawiska, takimi jak „zapobieganie” zmianom klimatu czy (precyzyjniej wobec realnych możliwości) ich „łagodzenie”.
} 
W naszym artykule opieramy się właśnie na podstawowym rozróżnieniu między działaniami zapobiegającymi, a raczej - patrząc realnie - łagodzącymi postępowanie zmian klimatu, a dostosowywaniem do tychże zmian.

Według szerokiej definicji adaptacją są wszelkie działania sprawiające, że dany system jest lepiej przygotowany do funkcjonowania w zmieniających się warunkach (Smit, Wandel 2006). Tak rozumianą adaptację można odnosić do systemów gospodarczo-społecznych nie tylko w kontekście presji czynników przyrodniczych, ale też cywilizacyjnych (np. terroryzm; por. Granberg, Glover 2012). W rezultacie zmian w systemach przyrodniczych i społecznych wrażliwość lokalnych systemów na skutki zmian klimatycznych powinna ulec zmniejszeniu, a sprężystość (ang. resilience ${ }^{3}$ ) zwiększeniu (Granberg, Glover 2012; por. zdolność adaptacyjna, Winsvold i in. 2009).

Orderud i Winsvold (2012) zwracają uwagę, że adaptacja do zmian klimatycznych często rozumiana jest jako wprowadzenie odpowiednich rozwiązań technologicznych, co - wobec przytoczonych definicji - jest podejściem bardzo zawężającym.

Adaptacja do zmian klimatu nie jest zjawiskiem nowym - ludzkość od wieków dostosowywała się do warunków środowiskowych (Matczak 2008). Różnica w stosunku do historycznych strategii radzenia sobie z naturą polega na odwoływaniu się do wyobrażeń o przyszłości, a nie - jak dawniej - do doświadczeń historycznych (Bulkeley, Tuts 2013). Nawiązanie do przyszłości pojawia się w samej definicji adaptacji, która stanowi odpowiedź na zachodzące bądź przewidywane impulsy klimatyczne i ich skutki, i obejmuje percepcję ryzyka oraz działania zmierzające do zmniejszenia potencjalnych szkód i wykorzystania nowo tworzących się możliwości (Granberg, Glover 2012; Bulkeley, Tuts 2013). Przygotowywanie się do przewidywanych w przyszłości zjawisk jest oczywiście znacznie trudniejsze niż reagowanie na pojawiające się problemy, stąd zmiany klimatu określono mianem ,wrednego problemu", ang. wicked problem (np. Hoppe i in. 2014).

Wyróżnia się działania zmierzające do likwidacji negatywnych skutków (np. klęsk żywiołowych czy ekstremalnych zjawisk pogodowych) - czyli powrót do stanu sprzed trudnego wydarzenia (ang. resilience as recovery) oraz działania transformujące zastane systemy $\mathrm{w}$ obliczu obecnych i oczekiwanych trudności (ang. resilience as transformation; Shaw, Theobald 2011). Zwykle adaptacją nazwany jest tylko mniej reaktywny, drugi typ działań. W takim ujęciu adaptacja to więcej niż „radzenie sobie” (ang. coping with) - wymaga refleksyjnej racjonalności i samoorganizacji, wysiłków celem przetworzenia wiedzy o obecnych i przyszłych zagrożeniach (Bulkeley, Tuts 2013). Nie oznacza to oczywiście, że takie dojrzałe działania przeważają w rzeczywistości - jak podsumowują badania słowami rozmówcy Hovik i in. (2011: 13): „Jak do tej pory, nie zrobiliśmy dużo, by dopasować się do przyszłych zmian klimatu, ale reagujemy na bieżące wyzwania, jak to robiliśmy także wcześniej”.

\footnotetext{
${ }^{3}$ Alternatywnym tłumaczeniem angielskiego terminu resilience może być odporność.
} 
Zapobieganie zmianom klimatu (ang. mitigation) jest głęboko osadzone w polityce zmniejszania szkodliwych emisji, w szczególności gazów cieplarnianych, do atmosfery. Działania łagodzące obejmują wszelkie przedsięwzięcia zmierzające do redukcji emisji zanieczyszczeń (Hamin, Guran 2008). Łagodzenie próbuje zatem zwalczać źródła problemu (por. Kundzewicz, Matczak 2012). Co ciekawe, na niwie lokalnej pojawił się trend używania łagodzenia jako elementu marketingu terytorialnego. Miasto jako miejsce przyjazne do życia może chwalić się dbałością o stan środowiska, w szczególności działaniami z zakresu ochrony klimatu (Gustavsson, Elander 2012).

W badaniach pojawia się określenie dychotomii adaptacja-łagodzenie, wskazujące że oba procesy powinny być traktowane jak bliźniacze (Hamin, Guran 2008). Jednocześnie w wielu przypadkach rozdział obu polityk pozostaje niejasny, a ich cele często na siebie nachodzą. Niektórzy autorzy twierdzą wręcz, że błędem jest rozdzielanie obu typów działań, jak często próbuje się robić przy tworzeniu programów je finansujących (Bulkeley, Tuts 2013). Niektóre działania ewidentnie służą obu celom naraz (np. zwiększanie powierzchni zielonych poprawia stan powietrza, a jednocześnie zwiększa możliwości absorpcji wód opadowych), inne łatwo je łączą (np. jeśli nowe budownictwo ma lepiej opierać się powodziom, to warto przy okazji zapewnić, by zużywało mniej wody i energii). Ale dychotomia wiąże się także z problemami w osiąganiu równocześnie celów obu typów działań. Przede wszystkim brakuje ich wzajemnej koordynacji, która zapewniałaby efekt synergii (Verchort i in. 2007; Hamin, Gurran 2008). Nie jest też jasne, co w praktyce ta synergia oznacza (Verchort i in. 2007). Uwaga powinna też zostać poświęcona aspektom kolizyjnym. Analizując działania z zakresu adaptacji i łagodzenia zmian klimatu w Australii i Stanach Zjednoczonych, Hamin i Gurran (2008) stwierdziły, że aż w połowie badanych przypadków cele obu typów polityk wzajemnie się wykluczają.

W tym miejscu warto przywołać koncepcję dysfunkcyjnej adaptacji (ang. maladaptation; Grandberg, Glover 2012), która zwraca uwagę na niepowodzenia adaptacji w osiąganiu zamierzonych celów czy wręcz osiąganie rezultatów przeciwnych poprzez zwiększenia wrażliwości systemu na skutki zmian klimatu bądź zwiększenie obciążenia klimatu. Jest to właśnie badana przez Hamin i Gurran kolizyjność adaptacji i łagodzenia. W podobny sposób można określić działania z zakresu ochrony środowiska, które de facto zwiększają presję na klimat, np. usuwanie azbestu.

\section{Działania podejmowane przez gminy i ich uwarunkowania}

Badania, które odnoszą się do obu typów polityk, wskazują, że na poziomie lokalnym przeważają działania łagodzące (Betsill, Bulkeley 2007; Granberg, Elander 2007; Hoppe i in. 2014). Analiza lokalnych polityk dotyczących ochrony klimatu w Holandii wykazała, że (wobec rozbudowanych programów łagodzących) adaptacja 
jest działaniem relatywnie zaniedbanym. Autorzy wyjaśniają ten stan rzeczy krajowymi programami wertykalnymi wspierającymi łagodzenie i brakiem podobnego wsparcia dla adaptacji oraz sprowadzeniem jej do wymiaru czysto lokalnych reakcji na (równie lokalne) problemy. Dyskurs zapobiegania zmianom klimatu został z kolei podniesiony do rangi problemu globalnego. Konieczność wielopoziomowego zarządzania w politykach klimatycznych sprawiła, że w literaturze wiele miejsca poświęca się rozważaniom o podziale kompetencji między szczebel narodowy a samorządy (Hovik i in. 2011; Hanssen i in. 2012).

Wyjaśniając przewagę działań łagodzących, Hoppe i in. (2014) zwracają też uwagę na wpływ dyskursu publicznego na podejmowanie działań adaptacyjnych lub zapobiegających zmianom klimatu. Według holenderskich badań zapobieganie kojarzone jest głównie z oszczędzaniem energii (a zatem także z oszczędnościami ekonomicznymi) i traktowane jako główny element polityk ochrony klimatu, podczas gdy adaptacja została w większości wchłonięta przez lokalną gospodarkę wodną i rzadko jest postrzegana jako część polityki klimatycznej. Podobne rozróżnienie obserwujemy w dyskursie polskim.

Wobec wynikającej z badań przewagi na poziomie lokalnym łagodzenia (zakorzenionego w dyskursie globalnym) nad adaptacją, warto sobie uzmysłowić, że jeszcze do końca ubiegłego wieku literatura naukowa również skupiała się na działaniach globalnych i międzynarodowych (Betsill, Bulkeley 2007: 448), potwierdzając niejako powszechną wątpliwość co do celowości podejmowania działań zapobiegających zmianom klimatu w skali lokalnej. Otto-Banaszak i in. (2011) zaobserwowali, że samorządy lokalne uważają się za zbyt małe, by samodzielnie radzić sobie ze skutkami zmian klimatu, co potwierdzają też nasze badania ${ }^{4}$.

Literatura dotycząca lokalnej polityki klimatycznej często skupia się na jednym lub drugim jej typie (Storbjörk 2007; Erdik, Durukal 2008; Matczak 2008; Horvik i in. 2011; Jackson, Lynch 2011; Baró i in. 2014), rzadko pojawiają się zbiorcze zestawienia prezentujące adaptację i łagodzenie. Terminy bywają też mylone (np. Erdik i Durukal 2008 piszą o mitygacji trzęsień ziemi). Z kolei Bulkeley i Tuts (2013) twierdzą, że większość dostępnej literatury koncentruje się na tym, co należałoby zrobić, a nie - co się robi, bo robi się mało. Choć przyznają, że to się stopniowo zmienia.

Wśród czynników determinujących formułowanie i wdrażanie polityk wobec zmian klimatu Koll i Schophaus (2004, za: Hoppe 2014) wymieniają przede wszystkim wielkość gminy, a także - skorelowane zazwyczaj z tą zmienną - dostępność wiedzy oraz profesjonalizm i doświadczenie kadr. Hoppe i in. (2014) wspominają

\footnotetext{
${ }^{4} 60 \%$ respondentów naszej ankiety zgodziło się ze stwierdzeniem, że , nasza gmina jest za mała, żeby prowadzić działania adaptacyjne”, a aż $70 \%$ ze stwierdzeniem, że „,nasza gmina jest za mało zamożna, żeby prowadzić działania adaptacyjne”.
} 
też o roli wielopoziomowego systemu polityki ochrony klimatu, m.in. o zachętach rządu centralnego (por. też: Betsill, Bulkeley 2007). Czynnikiem pojawiającym się we wszystkich opracowaniach jest dostęp do środków finansowych (np. Collier 1997; Bulkeley, Betsill 2003), ale ważne okazują się także: przeszłe zaangażowanie w działania dotyczące środowiska przyrodniczego na poziomie lokalnym, lokalne kompetencje, wiedza i umiejętności w zakresie polityk klimatycznych oraz przywództwo i wola polityczna. Wola polityczna jest wyjaśniana poprzez obecność ryzyka związanego ze zmianami klimatu, z antropopresją na środowisko (niska gęstość zabudowy, przemysł wydobywczy, niewielki procent zużycia energii odnawialnych) oraz z zasobami lokalnego społeczeństwa obywatelskiego do podjęcia działań w tym zakresie (np. liczbą organizacji pozarządowych z tego sektora; Zahran i in. 2008). Zahran i in. (2008) dodają do tej listy cechy politycznych instytucji (np. typ przywództwa) oraz stopień, w jakim można przedstawić dyskurs ochrony klimatu jako kwestię ekonomiczną (np. oszczędności w zużyciu energii).

W badaniu gmin holenderskich Hoppe i in. (2014) rozróżnili czynniki pozytywnie wpływające na adaptację i łagodzenie zmian klimatycznych. W przypadku adaptacji była to wielkość gminy (z której wynikała większa responsywność na inicjatywy narodowe oraz liczniejszy i lepiej wykształcony personel zajmujący się adaptacją). W odniesieniu do łagodzenia zidentyfikowano więcej czynników: polityki wertykalne wspierające łagodzenie zmian klimatu, uwaga mediów oraz związana z nią dyskusja między gminami, obecność w gminie wpływowego i zmotywowanego urzędnika zaangażowanego w tematykę ,proklimatyczną”, obecność publicznego aktywisty o zielono-lewicowej orientacji politycznej, wielkość gminy i jej udział w międzynarodowych sieciach związanych z ochroną klimatu (por. Hoppe, Coenen 2011).

Badając zaangażowanie miast amerykańskich w projekt Cities for Climate Protection (CCP), Zahran i in. (2008) zauważyli różnice społeczno-ekonomiczne i przyrodnicze między samorządami, które przystąpiły do inicjatywy, i tymi, które nie wzięły w niej udziału. Prawdopodobieństwo zaangażowania w CCP wzrastało wraz z doświadczeniami ekstremalnych zjawisk pogodowych (m.in. liczbą ich ofiar), prognozowanym wzrostem temperatury w danej miejscowości i bliskością wybrzeża, ale także z odsetkiem mieszkańców segregujących śmieci i głosujących na demokratów oraz z liczbą organizacji pozarządowych o profilu ekologicznym. Prawdopodobieństwo podejmowania takich działań malało z kolei w obszarach o wysokim zatrudnieniu w przemyśle wydobywczym.

O czynnikach determinujących adaptację do zmian klimatycznych pisali też Berkhout i in. (2006), ale ich uwaga skupiła się na mechanizmach uczenia się organizacji biznesowych. Ciekawym dla kontekstu polskiego wnioskiem jest postrzeganie rynku jako siły sprawczej działań adaptacyjnych przez firmy. Jak wynika z prowadzonych przez nas badań terenowych w ramach projektu PolCitClim, podobne skupienie na względach ekonomicznych obecne jest w dyskursie polskim, gdzie motywacją 
do działań są głównie oszczędności (np. dzięki modernizacji systemów ogrzewania albo termomodernizacji budynków), a nie ochrona klimatu.

Zagadnienia polityki samorządów wobec zmian klimatu, a zwłaszcza czynników wpływających na zróżnicowanie w tym zakresie, były jak dotąd znacznie rzadziej poruszane w badaniach polskich. Stosunkowo liczne są opracowania przygotowywane przez różnego rodzaju organizacje pozarządowe, niemające - ściśle rzecz ujmując - charakteru akademickiego i skupiające się bardziej na praktycznych rekomendacjach dla samorządów niż na wyjaśnieniach naukowych. Można tu przykładowo wymienić raport IMGW Zdqżyć przed powodziq (2005) czy raport Instytutu na rzecz Ekorozwoju (Raporto stanie... 2012), oparty na badaniu ankietowym powiatów, który to szczebel ma w praktyce znacznie mniejsze niż gminy możliwości oddziaływania na interesujące nas zagadnienia, a także Podręcænik adaptacji dla miast Ministerstwa Środowiska. Pojawiają się też opracowania dotyczące percepcji adaptacji do zmian klimatu wśród różnych grup społecznych (Kaniasty 2003; Otto-Banaszak i in. 2011;) czy teksty omawiające podstawy zagadnienia, jak np. pojęcie adaptacji, jej instytucjonalizację i przykłady takich polityk (Matczak 2008), przy czym dość częste jest odnoszenie adaptacji i łagodzenia do klęsk żywiołowych (Kundzewicz 2009; Kundzewicz, Matczak 2012).

\section{Pytania badaweze i metodyka pracy}

W nawiązaniu do przytoczonych rozważań nad rozróżnieniem adaptacji i łagodzenia oraz nad czynnikami determinującymi podejmowanie na szczeblu lokalnym działania sformułowaliśmy dwie grupy pytań badawczych: eksploracyjną i eksplanacyjną: - Jak często i jakie działania podejmują polskie gminy wobec zmian klimatu? Czy przeważa adaptacja czy łagodzenie? w jakim stopniu są to działania wspierane (narzucane) przez rząd centralny, w jakim takie, na które stosunkowo łatwo jest pozyskać zewnętrzne dofinansowanie, a w jakim są to lokalne przedsięwzięcia niestymulowane przez zewnętrzne czynniki?

- Jakie czynniki wyjaśniają zróżnicowanie działań podejmowanych przez samorządy lokalne?

W naszym badaniu koncentrujemy się na szczeblu gminnym, który w warunkach polskich jest najważniejszym szczeblem samorządowym (m.in. dysponującym największymi funduszami i odpowiadającym za najszerszy zakres zadań). Na podstawie literatury przedmiotu sformułowaliśmy kilka oczekiwań (hipotez) dotyczących czynników, od których może zależeć decyzja o wyborze strategii działań wobec zmian klimatu:

- Postrzegana podatność gminy na zagrożenia wiążące się z ekstremalnymi zja-

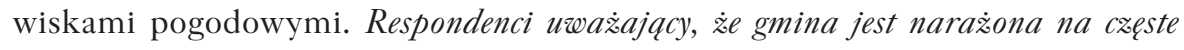




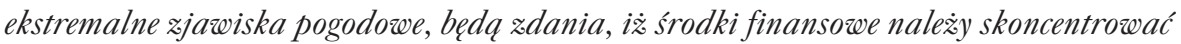
na minimalizowaniu skutkow tych sjawisk (a więc na dziataniach adaptacyjnych) (H1). Ogólniejsze działania zapobiegające zmianom klimatu będą traktowane w takiej sytuacji jako drugorzędne.

- Zamożność gminy55. Spodziewamy się, że gminy ubo:̇sze rzadziej niż zamożne będq podejmować dziatania tagodzqce (H2). Zakładamy, że gminy biedne mogą traktować działania łagodzące jako luksus, na który ich nie stać, muszą się bowiem koncentrować na rozwiązywaniu codziennych problemów. Poparcie dla działań zapobiegających zmianom klimatu powinno być więc większe w gminach zamożniejszych mogących na ten cel poświęcić „nadwyżki” pozostające po zaspokojeniu najbardziej podstawowych potrzeb.

- Wielkość gminy, mierzona liczbą mieszkańców. Spodziewamy się, że większe gminy będq cæéściej podejmować polityki klimatyczne (H3). Wynika to z tego, że - podobnie jak w bardzo wielu innych dziedzinach - to większe gminy są częściej innowatorami, a w polskich warunkach można traktować lokalne działania wobec zmian klimatu jako innowację. Ta innowacyjność większych miast wiąże się m.in. z większą możliwością specjalizacji w administracji samorządowej (a co za tym idzie większą liczbą ekspertów, którzy mogą zwracać uwagę na interesujące nas dziedziny), a także z zazwyczaj bardziej rozbudowanymi kontaktami zagranicznymi, pozwalającymi na przenoszenie doświadczeń z innych krajów. Wreszcie, duże miasta mają relatywnie większy wpływ na zmiany klimatu (zapobieganie może więcej zmienić), a konsekwencje niektórych zjawisk (np. fale upałów) są tam bardziej odczuwalne.

Oprócz analizy działań podejmowanych przez samorządy przyglądamy się też (patrz kolejny rozdział) indywidualnym preferencjom dotyczącym tych działań wśród osób zajmujących się sprawami klimatu w urzędach gminnych. W tym przypadku poza wymienionymi powyżej cechami gmin spodziewamy się, że znaczenie ma:

- Wiara w to, że zmiany klimatyczne rzeczywiście następują i że człowiek ma na nie wpływ. Spodziewamy się, że ci, którzy powatpiewaja we wptyw cztowieka na klimat będq niechętni wydawaniu środków na zapobieganie zmianom klimatu (H4). Będą koncentrować się przede wszystkim na działaniach adaptacyjnych, mających znaczenie dla zapobiegania szkodom związanym np. z powodziami, bez względu na to, jaki jest charakter przyczyn tych zjawisk. Jeśli będą interesować się działaniami łagodzącymi, to tylko ze względu na dostępne na te cele środki zewnętrzne (np. z funduszy unijnych), a pożądanymi skutkami będzie np. zmniejszenie zuży-

\footnotetext{
${ }^{5}$ Zmienna ta operacjonalizowana jest zgodnie z metodą stosowaną w rankingu zamożności pisma „Wspólnota” (szczegóły por. Swianiewicz, Łukomska 2014). Uwzględnia ona przeliczone na jednego mieszkańca dochody budżetowe z wyłączeniem dotacji celowych, składek na poziomy system wyrównawczy, a powiększonych o zastosowane przez władze lokalne obniżki stawek i ulgi w podatkach lokalnych.
} 
cia energii albo poprawa jakości powietrza, a nie zapobieganie samym zjawiskom klimatycznym. Osoby zaś uważające, że zmiany klimatyczne to ważny współczesny problem, będą skłonne poświęcać więcej środków na zmniejszanie skali tych zmian. Oczekujemy więc, że odpowiedź na pytanie będące zmienną zależną w naszym modelu będzie związane z opiniami dotyczącymi wiary w zmiany klimatu i ogólniejszym przekonaniem, że władze lokalne powinny podejmować działania w tym zakresie. Pośrednio kwestia wiary w realność zagrożeń związanych ze zmianami klimatycznymi pojawia się też w analizach zawartych w następnym rozdziale, ale w tym przypadku odnosi się nie do indywidualnych cech i przekonań respondentów, a do ogólniejszej charakterystyki społeczności lokalnych. Oczekujemy mianowicie, że poparcie dla dziatań tagodzqcych będzie mniejsze w regionach, w których duïe poparcie majq partie polityczne czesto podkreślajqce swój sceptycyzm w sprawie samian klimatycznych (np. KORWIN, ale także $\mathrm{PiS}^{6}$ ), a większe w regionach z większym poparciem dla partii lewicowych (H5).

Nasze analizy empiryczne opierają się na materiale z badania ankietowego przeprowadzonego wśród polskich gmin w 2014 r. w ramach projektu PolCitClim (por. przyp. 1). Przedstawiciele gmin (zajmujący się sprawami dotyczącymi lokalnej polityki klimatycznej) mogli wypełnić kwestionariusz on-line (CAWI) lub w wersji tradycyjnej. Otrzymaliśmy 1311 zwrotów, a zatem baza obejmuje ponad połowę gmin w Polsce. Jak wynika z naszych analiz, jest to zbiór reprezentatywny pod względem wielkości i położenia regionalnego.

Analiza otrzymanych odpowiedzi opiera się na następujących założeniach metodologicznych:

- pytając o działania rzeczywiście podejmowane przez samorządy (analizy w następnych rozdziałach) traktujemy odpowiedzi jako odwzorowanie rzeczywistości, a czynników wyjaśniających zróżnicowanie szukamy wśród cech środowiska społeczno-gospodarczego i przyrodniczego, w którym znajduje się respondent;

- pytając o indywidualne preferencje respondenta dotyczące adaptacji lub łagodzenia, odwołujemy się do wyjaśnień mających źródło zarówno w środowisku społeczno-gospodarczym (mającym wpływ na indywidualne preferencje), jak i do elementów zakorzenionych w przekonaniach respondenta odnoszących się do zmian klimatu.

\footnotetext{
${ }^{6} \mathrm{Na}$ przykład obecny minister środowiska Jan Szyszko wielokrotnie w swoich wypowiedziach podważał zarówno samo zjawisko zmian klimatu, jak i wpływ nań działalności człowieka (wypowiedź z 2013r.: http:// www.stefczyk.info/publicystyka/opinie/szyszko-globalne-ocieplenie-bylo-decyzja-polityczna,9085670552, 20.02.2017; oraz z 2015r.: http://naukaoklimacie.pl/fakty-i-mity/mit-zmiana-klimatu-to-nie-problem-botak-twierdzi-swiatowa-federacja-naukowcow-115, 20.02.2017). Z kolei Janusz Korwin-Mikke na swojej stronie internetowej zamieszcza liczne wpisy podważające teorię wpływu człowieka na zmiany klimatu (http://korwin-mikke.pl/szukaj/tag/klimat, 20.02.2017).
} 


\section{Działania podejmowane wobec zmian klimatu}

Respondenci ankiety proszeni byli o wymienienie działań odnoszących się do zmian klimatu, przy czym w ankiecie znalazło się zwięzłe wyjaśnienie terminów adaptacja i zapobieganie zmianom klimatycznym ${ }^{7}$.

Podobnie jak w przytaczanych badaniach zagranicznych, gminy polskie objęte badaniem znacznie częściej deklarowały realizację zadań z zakresu łagodzenia zmian klimatu (46,8\% badanych gmin) niż adaptacji do nich (21,4\%). Wprawdzie część z tych deklaracji okazała się błędna (respondenci mylili adaptację z łagodzeniem - 6,4\%, lub podawali działania w ogóle niezwiązane z ochroną klimatu $-5,1 \%{ }^{8}$ ), ale nawet uwzględniając te pomyłki, działań zapobiegających jest znacznie więcej.

Uszczegóławiając analizy, przyjrzeliśmy się konkretnym deklarowanym działaniom. Jeśli przyjąć termomodernizację jako działanie głównie łagodzące, gmin deklarujących tylko zmniejszanie oddziaływania na klimat było w naszej bazie $426(32,5 \%)$, podczas gdy tylko adaptację zgłosiło 48 gmin (3,7\%), a oba działania 165 samorządów $(12,6 \%$; ryc. 1$)$.

Działania zapobiegające otwiera zdecydowanie najpopularniejsza termomodernizacja, choć warto pamiętać, że można ją traktować także jako swoistą adaptację (szczelny budynek lepiej chroni przed upałami ${ }^{9}$ ). W dalszej kolejności wymieniane są bardziej jednoznaczne inwestycje związane z redukcją emisji zanieczyszczeń. Działania dotyczące ograniczania niskiej emisji dotyczyły gazyfikacji gmin, wymiany kotłów ciepłowniczych, a także wdrażania planów gospodarki niskoemisyjnej oraz ograniczania niskiej emisji. Wśród odnawialnych źródeł energii najpopularniejsza jest fotowoltaika, tylko pojedyncze gminy wskazywały elektrownie wodne, wiatrowe czy spalarnie biomasy. Mniej niż 5\% badanych gmin deklarowało edukację i promocję, najczęściej dotyczące gospodarki niskoemisyjnej i ograniczania niskiej emisji, a także energooszczędne oświetlenie ulic, inwestycje w transport publiczny (wymianę taboru autobusowego na niskoemisyjny, budowę ścieżek rowerowych) oraz zwiększanie zielonych powierzchni (co można traktować jako działanie z pogranicza adaptacji i zapobiegania).

\footnotetext{
${ }^{7}$ Pod pojęciem łagodzenia (mitygacji) rozumiemy ,zapobieganie zmianom klimatycznym poprzez ograniczanie niekorzystnego wpływu działalności człowieka na klimat (np. redukcja emisji dwutlenku węgla, termomodernizacja budynków)”, adaptacją natomiast nazywamy „przystosowanie się do zmian klimatycznych i ich konsekwencji (np. budowa zbiorników retencyjnych, przystosowanie budynków do okresowych podtopień lub huraganowego wiatru)" (sformułowania z ankiety).

${ }^{8}$ Respondenci albo mylili obie polityki, albo traktowali je jako określenia tego samego zjawiska. Co ciekawe, znacznie więcej błędnych przyporządkowań zrodziła adaptacja niż łagodzenie. 8\% samorządów deklarujących działania łagodzące podało co najmniej jedno działanie mające charakter adaptacji. Z kolei wśród deklarujących działania adaptacyjne błędne odpowiedzi pojawiały się w 38\% przypadków. ${ }^{9}$ Ze względu na tę niejednoznaczność w dalszych analizach dotyczących adapatcji zamieszczamy wersję z i bez termomodernizacji.
} 
Procent gmin podejmujących najpopularniejsze działania

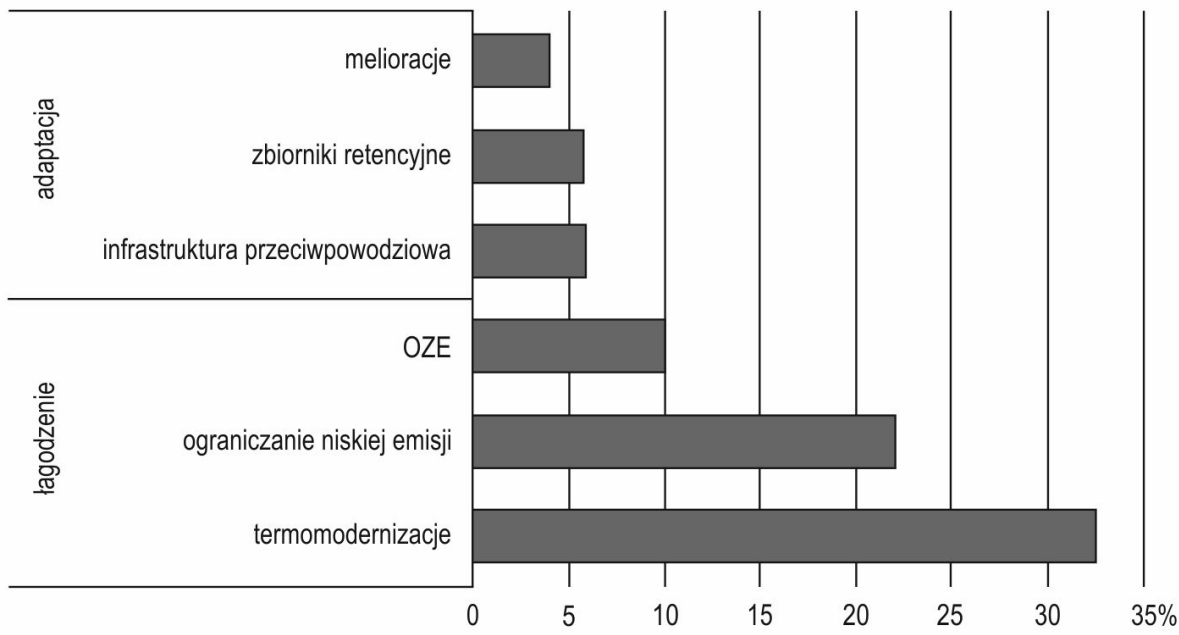

Ryc. 1. Popularność działań adaptacyjnych i łagodzących w badanych gminach

Fig. 1. Most frequent adaptation and mitigation activities undertaken by investigated communes

Określenie konkretnych podejmowanych działań skłania do dwóch refleksji. Po pierwsze, ich struktura wykazuje wyraźny związek z zewnętrznymi zachętami lub/i odgórnymi wymogami, co podaje w wątpliwość „endogeniczne”, ekologiczne pobudki działań, przypomina raczej dopasowywanie się do systemu. Termomodernizacja czy fotowoltaika to inwestycje, na które od kilku lat są dostępne zewnętrzne źródła finansowania (głównie z funduszy UE, ale także z NFOŚiGW). Zachęta finansowa jest „wzmacniana” przez polskie regulacje. W nowej perspektywie finansowej 2014-2020 podstawą wsparcia z Programu Operacyjnego Infrastruktura i Środowisko (POIiŚ) w ramach priorytetów inwestycyjnych realizujących cele ochrony klimatu są lokalne dokumenty strategiczne, spełniające wymogi strategii niskoemisyjnych. A zatem gminy, które chcą pozyskać pieniądze m.in. na działania w zakresie termomodernizacji budynków, na wykorzystywanie odnawialnych źródeł energii czy modernizację transportu publicznego, muszą posiadać plany gospodarki niskoemisyjnej (PGN). Ich opracowanie jest współfinansowane z Funduszy Spójności (85\% dofinansowania). Pomysł wymogu oparto na funkcjonującym od 2008 r. 
europejskim Porozumieniu burmistrzbrw, firmowanym przez Komisję Europejską dobrowolnym zrzeszeniu gmin deklarujących realizację celów unijnej polityki energetyczno-klimatycznej na poziomie lokalnym (realizacja pakietu 3x20, Misja: Emisja). Lokalne plany gospodarki niskoemisyjnej i programy obniżania niskiej emisji (PONE) wpisują się w Krajowy Program Ochrony Powietræa do roku 2020 (2015).

Po drugie, co jeszcze bardziej podważa lokalną świadomość konieczności ochrony klimatu, łatwo dostrzec motywację ekonomiczną wymienianych działań. Argumentem dla lokalnych decydentów niekoniecznie jest zapobieganie zmianom klimatu, tylko oszczędności (stanowiące prostą pochodną choćby gospodarki niskoemisyjnej). Jak wynika z wywiadów, które przeprowadziliśmy w ramach badań terenowych, łagodzenie zmian klimatu pojawia się często „przy okazji”, głównie jako hasło pomagające w zdobywaniu dodatkowych funduszy. W programie politycznym prezentowanym mieszkańcom ważniejszy jest sam argument oszczędności oraz pozyskania zewnętrznych środków (co odbierane jest jako przejaw aktywności i zaradności samorządu).

Deklarowane działania adaptacyjne niemal w całości dotyczyły zapobiegania powodziom lub suszom. Oprócz działań wymienionych na ryc. 1 niecałe $2 \%$ gmin wymieniło regulację cieków oraz inwestycje w kanalizację deszczową. Wśród sporadycznych odpowiedzi pojawiały się informacje o usuwaniu skutków silnych wiatrów i opadów śniegu. Samorządy nie wymieniały działań przeciwko upałom (np. kurtyn wodnych), choć wiemy, że takie działania pojawiają się czasem, głównie w wielkich miastach.

Relatywnie często respondenci wymieniali działania, które dotyczą raczej dbania o czystość środowiska przyrodniczego niż o klimat: usuwanie azbestu, instalację przydomowych oczyszczalni ścieków, kanalizowanie i wodociągowanie gminy, modernizację oczyszczalni ścieków, uszczelnianie szamb (ponad 5\% gmin). Potwierdza to obserwacje z innych badań (materiał z wywiadów PolCitClim), wskazujących, że w Polsce nadal bardziej rozpowszechniona jest świadomość dotycząca antropopresji i ochrony środowiska niż zagadnienia związane ze zmianami klimatycznymi. Ale wyniki są też zbliżone do uzyskanych np. w Holandii (Hoppe i in. 2014). Badając polityki adaptacji i łagodzenia w gminach holenderskich między 1998 a 2013 r., Hoppe i in. (2014) odkryli, że o ile większość samorządów prowadzi działania łagodzące, o tyle adaptacja znajduje się poza lokalnymi priorytetami. Autorzy wyjaśniają taki stan rzeczy centralną polityką wspierającą wertykalnie zintegrowane działania na rzecz zapobiegania zmianom klimatu i brakiem programów wspierających (także finansowo) adaptację. Obserwacje holenderskie są spójne z wynikami naszego badania - łagodzenie postrzegane jest jako komponent polityki energetycznej, a adaptacja kojarzona z problemami dotyczącymi wody. Tak jak w Polsce, tak i w Holandii gminy rzadko skupiały się na działaniach adaptacyjnych niedotyczących powodzi. 
Zanim przejdziemy do badań uwarunkowań podejmowanych działań, zobaczmy jeszcze, czy przedstawiony wyżej ich obraz jest zgodny z preferencjami naszych respondentów. W badaniu ankietowym zapytaliśmy, jaką część środków (przy ograniczonej puli zasobów) należałoby przeznaczać na zapobieganie zmianom klimatu (cel A w ankiecie), a jaką część na adaptację (cel B).

Niemal jedna trzecia respondentów $(30,3 \%)$ wybrała równy podział środków na cele A i B. Odpowiedzi pozostałych układają się niemal symetrycznie - tzn. niemal równie liczni są zwolennicy przewagi środków przeznaczanych na zapobieganie jak ci, którzy uważają, że więcej środków należy wydawać na adaptację. Obserwujemy wprawdzie bardzo niewielką przewagę zwolenników podejmowania działań w zakresie adaptacji, ale różnica tutaj jest minimalna (ryc. 2), co zaskakuje zarówno w świetle przywoływanych wyników badań zagranicznych, jak i naszej analizy podejmowanych działań, według których na poziomie lokalnym rysuje się znaczna przewaga łagodzenia.

\section{Procent środków jaki powinien być wydawany na mitygację (pozostała część na adaptację do zmian klimatycznych)}

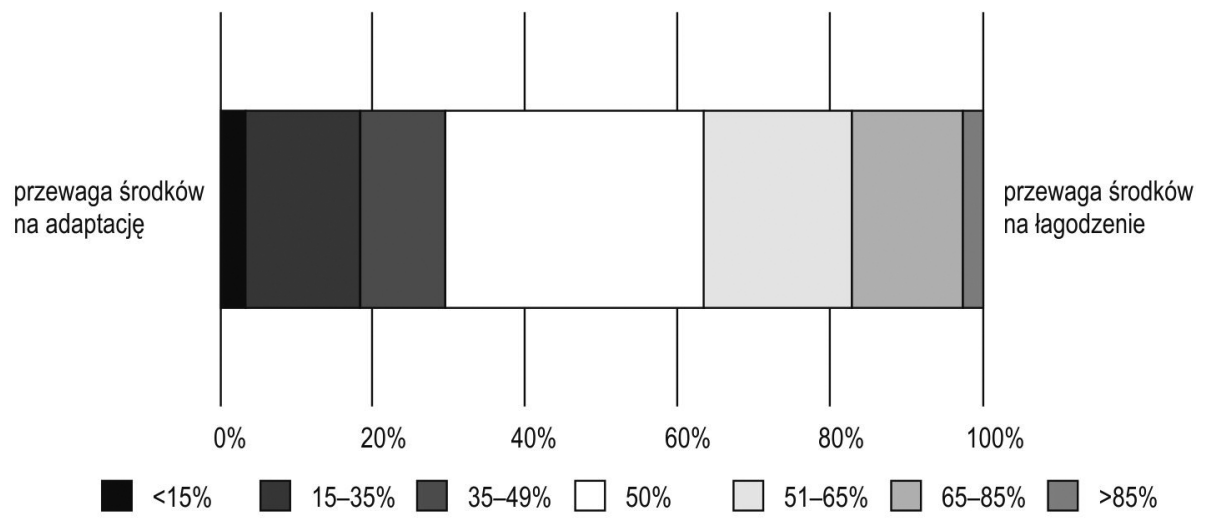

Ryc. 2. Rozkład środków pomiędzy działania łagodzące i adaptacyjne, uznany za optymalny przez respondentów

Fig. 2. Structure of financial resources dedicated to mitigation and adaptation preferred by the respondents 


\section{Zależności działań i preferowanych typów lokalnej polityki klimatyeznej od cech gmin}

\section{Czynniki wyjaśniające podejmowanie działań wobec zmian klimatu}

Odwołując się do naszych hipotez, sprawdzamy, czy podejmowanie w gminie działań łagodzących lub adaptacyjnych ma związek z:

- postrzeganym zagrożeniem skutkami ekstremalnych zjawisk pogodowych ${ }^{10}$; zmienna ta może przyjmować wartości od 0 do 22; dodatkowo testowaliśmy także zagrożenie ekstremalnymi zjawiskami „wodnymi” (powodzie, gwałtowne deszcze), w tym przypadku wartości zmiennej mogą się wahać od 0 do 8;

- wielkością gminy (liczbą mieszkańców) ${ }^{11}$;

- zamożnością gminy mierzoną wielkością dochodów budżetowych w przeliczeniu na jednego mieszkańca.

Dodatkowo sprawdziliśmy także, czy ma znaczenie orientacja polityczna społeczności lokalnej mierzona skłonnością do głosowania w wyborach parlamentarnych na największe partie polityczne.

Zacznijmy od zbadania prostych związków między zmiennymi wyjaśniającymi i wyjaśnianymi.

Jak wynika z tab. 1, zebrane dane potwierdzają niektóre ze spodziewanych zależności. Zarówno działania zapobiegające, jak i adaptacyjne częściej podejmują gminy duże, takie, w których ponadprzeciętne poparcie zdobywa Platforma Obywatelska, a także Partia Razem, niższe zaś niż przeciętne Prawo i Sprawiedliwość oraz PSL. Działania takie są częstsze także w gminach, w których podatność na ekstremalne zjawiska pogodowe związane z gospodarką wodną jest częstsza. Co ciekawe, kiedy braliśmy pod uwagę wszystkie zagrożenia ekstremalnymi zjawiskami pogodowymi, nie pojawiała się zależność działań łagodzących, a w zakresie działań adaptacyjnych kierunek tej zależności był odwrotny od spodziewanego. Nie widać natomiast związku między aktywnością gmin a ich zamożnością.

Zależności między pojedynczymi zmiennymi mogą być jednak o tyle mylące, że poszczególne zmienne wyjaśniające nie są od siebie niezależne. Na przykład poparcie wyborcze dla PSL czy PiS jest zazwyczaj wyższe w małych gminach.

\footnotetext{
${ }^{10}$ Zmienną niezależną jest w tym przypadku indeks oparty na dwóch pytaniach: (1) Czy Pana(i) gmina doświadczyła w ciągu ostatnich 10 lat zjawisk pogodowych, które można uznać za ekstremalne? i (2) Czy gmina, według Pana(i) oceny, jest zagrożona wystąpieniem któregoś z poniższych zjawisk w niedalekiej przyszłości? Pytaniom towarzyszyła lista 11 ekstremalnych zjawisk pogodowych (m.in. powódź, susza, ulewne deszcze, huragan, upały, mrozy).

${ }^{11} \mathrm{~W}$ analizach regresji ze względu na rozkład statystyczny zmiennej posługiwaliśmy się logarytmem naturalnym liczby mieszkańców.
} 
Tab. 1. Przeciętne wartości zmiennych wyjaśniających w gminach podejmujących i niepodejmujących działań łagodzących/adaptacyjnych

Table 1. Mean values of explanatory variables in communes undertaking and withstanding from mitigation/adaptation

\begin{tabular}{|c|c|c|c|c|c|c|}
\hline & \multicolumn{2}{|c|}{$\begin{array}{c}\text { Łągodzenie } \\
\text { (z termomodernizacją) } \\
\text { Mitigation (with } \\
\text { thermomodernisation) }\end{array}$} & \multicolumn{2}{|c|}{$\begin{array}{c}\text { Adaptacja } \\
\text { (z termomodernizacją) } \\
\text { Adaptation (with } \\
\text { thermomodernisation) }\end{array}$} & \multicolumn{2}{|c|}{$\begin{array}{c}\text { Adaptacja } \\
\text { (bez termomodernizacji) } \\
\text { Adaptation (without } \\
\text { thermomodernisation) }\end{array}$} \\
\hline & $\begin{array}{l}\text { Nie } \\
\text { No }\end{array}$ & $\begin{array}{l}\text { Tak } \\
\text { Yes }\end{array}$ & $\begin{array}{l}\text { Nie } \\
\text { No }\end{array}$ & $\begin{array}{l}\text { Tak } \\
\text { Yes }\end{array}$ & $\begin{array}{l}\text { Nie } \\
\text { No }\end{array}$ & $\begin{array}{l}\text { Tak } \\
\text { Yes }\end{array}$ \\
\hline $\begin{array}{l}\text { Postrzegana podatność } \\
\text { na wszelkie ekstremalne } \\
\text { zjawiska pogodowe (indeks) } \\
\text { Perceived vulnerability } \\
\text { to extreme weather events } \\
\text { (index) }\end{array}$ & 8,0 & 7,8 & $8,1^{\star \star}$ & $7,6^{\star *}$ & $8,0^{\text {** }}$ & $7,4^{\star *}$ \\
\hline $\begin{array}{l}\text { Postrzegana podatność } \\
\text { na ekstremalne zjawiska } \\
\text { „wodne” (powódź, deszcz, grad) } \\
\text { Perceived vulnerability } \\
\text { to extreme „water” events } \\
\text { (flood, heavy rain, hail) }\end{array}$ & $2,8^{\star \star}$ & $3,1^{* *}$ & $2,8^{\star *}$ & $3,1^{\star *}$ & $2,8^{\star \star}$ & $3,6^{* *}$ \\
\hline $\begin{array}{l}\text { \% głosów na PIS } 2015 \\
\% \text { of votes for PiS } 2015\end{array}$ & $43,9^{*}$ & $42,4^{*}$ & $44,0^{*}$ & $42,1^{*}$ & $43,5^{\star}$ & $41,6^{*}$ \\
\hline $\begin{array}{l}\text { \% głosów na PO } 2015 \\
\% \text { of votes for PO } 2015\end{array}$ & $17,3^{\star *}$ & $19,5^{\star \star}$ & $17,4^{\star * *}$ & $19,6^{\text {** }}$ & $17,9^{\star \star *}$ & $20,5^{\star}$ \\
\hline $\begin{array}{l}\text { \% głosów na Razem } 2015 \\
\% \text { of votes for Razem } 2015\end{array}$ & $2,9^{* *}$ & $3,1^{\star *}$ & $2,9^{* *}$ & $3,1^{* *}$ & 3,0 & 3,0 \\
\hline $\begin{array}{l}\% \text { głosów na Kukiz } 2015 \\
\% \text { of votes for Kukiz } 2015\end{array}$ & 9,3 & 9,3 & 9,3 & 9,2 & 9,3 & 9,3 \\
\hline $\begin{array}{l}\text { \% głosów na PSL } 2015 \\
\% \text { of votes for PSL } 2015\end{array}$ & $11,0^{* * *}$ & $8,8^{\star * *}$ & $10,8^{* * *}$ & $8,8^{\star \star \star}$ & $10,4^{\star \star \star}$ & $8,0^{* * *}$ \\
\hline $\begin{array}{l}\text { \% głosów na ZLEW } 2015 \\
\% \text { of votes for ZLEW } 2015\end{array}$ & 6,2 & 6,4 & 6,2 & 6,5 & 6,3 & 6,3 \\
\hline $\begin{array}{l}\text { Zamożność } \\
\text { Wealth }\end{array}$ & 2573 & 2624 & 2587 & 2611 & 2583 & 2663 \\
\hline $\begin{array}{l}\text { Liczba ludności } \\
\text { Number of habitants }\end{array}$ & $10320^{\star \star * *}$ & $22505^{\star \star \star}$ & $12789^{\star * *}$ & $20467^{* * *}$ & $14125^{\star * *}$ & $24720^{* * *}$ \\
\hline
\end{tabular}

Uwaga: ${ }^{*}$ - różnice istotne statystycznie na poziomie 0,$05 ;{ }^{* *}$ - na poziomie 0,$01 ;{ }^{* * *}$ - na poziomie 0,001 Caution: ${ }^{*}$ - differences statistically significant at the level of $0.05,{ }^{* *}-$ at the level of $0.01,{ }^{* * *}-$ at the level of 0.001 . 
Czy zatem obserwowana zależność wiąże się bardziej z wielkością gminy czy z preferencjami dla poszczególnych ugrupować politycznych i ich programów oraz głoszonych przez nie wartości? Żeby to sprawdzić, posłużymy się modelami regresji, w których zmiennymi zależnymi są kolejno podejmowanie działań mitygacyjnych i adaptacyjnych. Ze względu na charakter tych zmiennych posłużymy się modelami regresji logistycznej. Zmiennymi niezależnymi są zaś podatność na ekstremalne zjawiska pogodowe, wielkość gminy (ze względu na rozkład tej zmiennej posłużymy się logarytmem naturalnym liczby ludności), zamożność oraz poparcie w wyborach 2015 dla poszczególnych ugrupowań politycznych, które wykazywały największy związek ze zmienną zależną w analizach jednozmiennych.

Okazuje się, że podstawową zmienną wyjaśniającą jest wielkość (liczba ludności) gminy. Im większa gmina, tym wyższe prawdopodobieństwo podejmowania przez nią polityki klimatycznej - zarówno łagodzącej, jak i adaptacyjnej (por. wyniki w tab. 2 i 3). Jeśli chodzi o działania łagodzące, żadna z pozostałych zmiennych niezależnych modelu nie okazała się istotna statystycznie. Być może ma to związek z zauważoną zależnością działań łagodzących od zachęt i wymogów zewnętrznych.

Jeśli natomiast przyglądamy się działaniom o charakterze adaptacji do zmian klimatycznych, istotna okazuje się też podatność gminy na ekstremalne zjawiska pogodowe - im częściej są one obserwowane, tym częściej podejmuje się działania adaptacyjne (choć i w tym przypadku istotność wielkości gminy okazała się minimalnie większa). W żadnym z modeli nie potwierdziła się istotność preferencji

Tab. 2. Model wyjaśniający podejmowanie działań łagodzących - regresja logistyczna Table 2. Explanatory model for undertaking mitigation activities - logistic regression

\begin{tabular}{|c|c|c|c|}
\hline \multicolumn{4}{|c|}{$\begin{array}{c}\text { R2 Nagelerkego 0,087 } \\
\text { Logarytm wiarygodności (log likelihood) } 1711,9 \\
\text { Istotność modelu (model's significance): test Chi-kwadrat }-0,000, N=1312\end{array}$} \\
\hline & $B$ & Błąd stand. & $\operatorname{Exp}(B)$ \\
\hline $\begin{array}{l}\text { Ln ludność } 2013 \\
\text { Ln population size } 2013\end{array}$ & 0,577 & 0,088 & $1,780\left(^{* \star *}\right)$ \\
\hline $\begin{array}{l}\text { Zamożność } 2013 \\
\text { Wealth } 2013\end{array}$ & 0,000 & 0,000 & 1,000 \\
\hline $\begin{array}{l}\text { Podatność na ekstremalne zjawiska wodne } \\
\text { Vulnerability to extreme water events }\end{array}$ & 0,045 & 0,033 & 1,046 \\
\hline $\begin{array}{l}\% \text { głosów na PiS } \\
\% \text { of votes for PiS }\end{array}$ & 0,000 & 0,010 & 1,000 \\
\hline $\begin{array}{l}\% \text { głosów na PO } \\
\% \text { of votes for PO }\end{array}$ & 0,005 & 0,016 & 1,005 \\
\hline $\begin{array}{l}\% \text { głosów na PSL } \\
\% \text { of votes for PSL }\end{array}$ & $-0,009$ & 0,013 & 0,991 \\
\hline
\end{tabular}


Tab. 3. Model wyjaśniający podejmowanie działań adaptacyjnych - regresja logistyczna Table 3. Explanatory model for undertaking adaptation activities - logistic regression

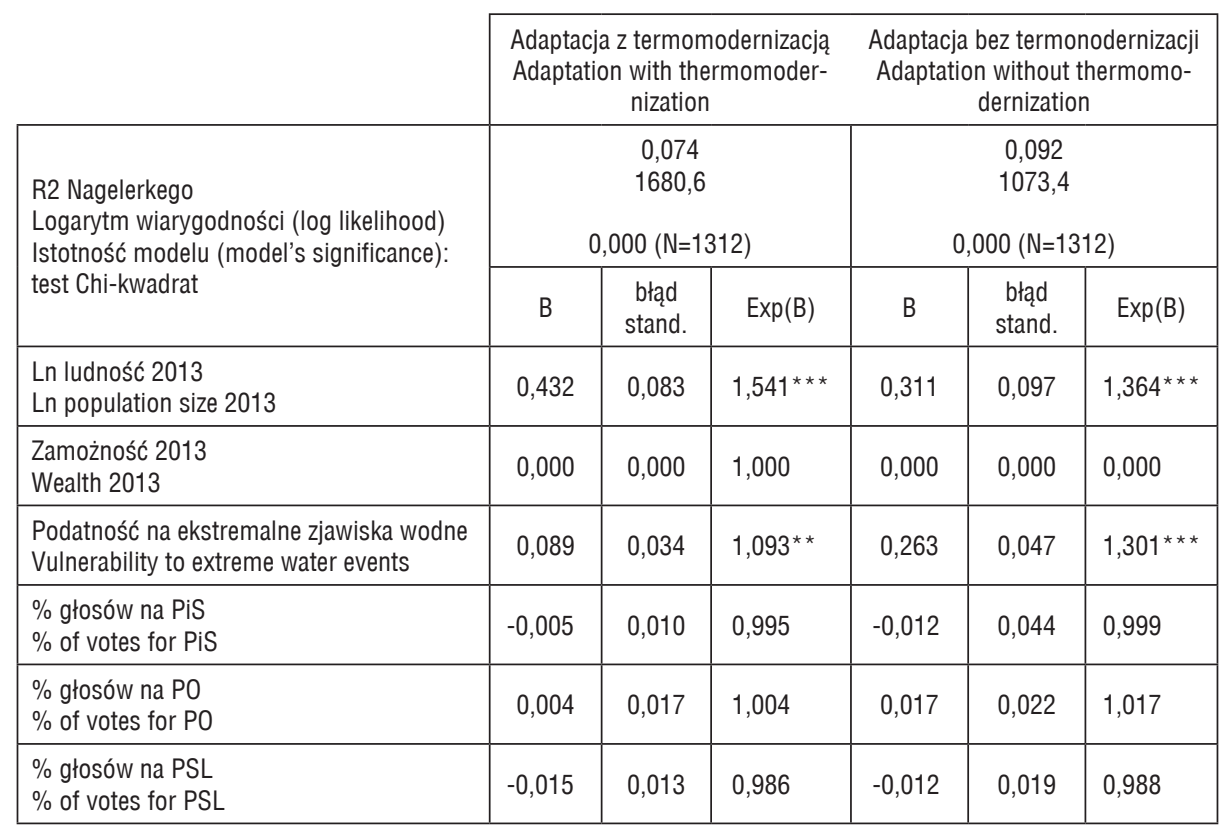

wyborczych społeczności lokalnych. Zależność od orientacji politycznej zanotowana w wynikach prezentowanych w tab. 1 okazuje się zatem wtórna w stosunku do zmiennej określającej wielkość gminy.

\section{Preferencje respondentów w zakresie działań łagodzących i adaptacyjnych}

W poprzedniej sekcji analizowaliśmy deklaracje dotyczące podejmowanych przez samorządy działań. Nie muszą być one jednak tożsame z preferencjami naszych respondentów - osób, które w samorządach odpowiadają za sprawy ochrony środowiska, w tym za politykę klimatyczną. W tej części zajmiemy się determinantami preferencji dotyczących adaptacji lub łagodzenia. W prezentowanych dalej analizach statystycznych przedstawiamy czynniki sprzyjające preferowaniu działań na rzecz łagodzenia zmian klimatu. Sformułowanie naszego pytania ankietowego (por. ryc. 2) implikuje, że czynniki wyjaśniające wsparcie dla adaptacji są lustrzanym odbiciem tych wyników. 
Przyjrzyjmy się najpierw współczynnikom korelacji pokazującym związek między potencjalnymi zmiennymi wyjaśniającymi i skłonnością do poświęcania środków na zapobieganie zmianom klimatycznym (tab. 4).

Okazuje się, że najwyższy związek skłonność do zajmowania się łagodzeniem zmian klimatycznych wykazuje ze zmiennymi obrazującymi poziom wiary we wpływ człowieka na klimat. Zauważalny związek odnosi się także do lokalizacji gminy w regionie odznaczającym się wysokim poparciem, jakie w wyborach uzyskało PiS (negatywny wpływ na skłonność do polityki mitygacji) oraz PO i Zjednoczona Lewica (w tym przypadku wpływ jest pozytywny). Nie wykazuje natomiast związku z postrzeganym poziomem zagrożeń ekstremalnymi zjawiskami pogodowymi danej

Tab. 4. Współczynniki korelacji między częścią środków przeznaczanych na „cel A” - zapobieganie zmianom klimatycznym i potencjalnymi zmiennymi wyjaśniającymi

Table 4. Correlation coefficients between the percentage of means dedicated to mitigation activities and potential explanatory variables

\begin{tabular}{|l|c|}
\hline $\begin{array}{l}\text { Postrzegana podatność na wszelkie ekstremalne zjawiska pogodowe } \\
\text { Perceived vulnerability to all extreme weather events }\end{array}$ & 0,002 \\
\hline $\begin{array}{l}\text { Ekstremalne zjawiska pogodowe w gminie spowodowane są globalnymi zmianami klimatycznymi } \\
\text { Extreme weather evets in a commune caused by global climate changes }\end{array}$ & $0,237^{\star *}$ \\
\hline $\begin{array}{l}\text { Dowody na wpływ człowieka na zmiany klimatyczne są przekonujące } \\
\text { Proofs of human influence on climate change are convincing }\end{array}$ & $0,220^{\star *}$ \\
\hline $\begin{array}{l}\text { Zmiany klimatu to poważny i pilny problem, trzeba podjąć działania nawet jeśli wiąże się to } \\
\text { ze znacznymi kosztami } \\
\text { Climate change is an important and urgent problem, it should be delt with even at high costs }\end{array}$ & $0,213^{\star *}$ \\
\hline $\begin{array}{l}\text { Władze lokalne powinny podejmować działania związane ze zmianami klimatycznymi } \\
\text { Local authorities should undertake actions related to climate change }\end{array}$ & $0,085^{\star *}$ \\
\hline $\begin{array}{l}\text { Wykształcenie respondenta } \\
\text { Respondent's education }\end{array}$ & $-0,005$ \\
\hline $\begin{array}{l}\text { \% głosów na PiS w wyborach } 2015 \\
\% \text { of votes for PiS in elections } 2015\end{array}$ & $-0,071^{*}$ \\
\hline $\begin{array}{l}\text { \% głosów na PO w wyborach } 2015 \\
\% \text { of votes for PO in elections } 2015\end{array}$ & $0,062^{\star}$ \\
\hline $\begin{array}{l}\text { \% głosów na ZLew w wyborach } 2015 \\
\% \text { of votes for Zlew in elections } 2015\end{array}$ & $0,063^{*}$ \\
\hline $\begin{array}{l}\text { Zamożność gminy } \\
\text { Commune wealth }\end{array}$ & $-0,013$ \\
\hline $\begin{array}{l}\text { Liczba ludności gminy (In) } \\
\text { Population size (In) }\end{array}$ & 0,023 \\
\hline
\end{tabular}

* - współczynniki korelacji istotne na poziomie $0,05,{ }^{* *}$ - współczynniki korelacji istotne na poziomie 0,01 .

* - correlation coefficients significant at the level of $0.05,{ }^{* *}-$ at the level of 0.01 . 
gminy, a także z jej poziomem zamożności. Co ciekawe, poglądy respondentów w interesującym nas tutaj zakresie nie wykazują też istotnego związku z poziomem wykształcenia.

Dodatkową ilustracją związków korelacyjnych są dane zawarte w tab. 5. Respondenci mający przekonanie o realności zmian klimatycznych wywoływanych przez człowieka sądzą, że na zapobieganie powinniśmy wydawać nieco więcej środków niż na adaptację. Ci zaś, którzy są w tej sprawie sceptyczni, uważają, że jeżeli w ogóle mamy wydawać jakieś środki na działania związane ze zjawiskami pogodowymi, to trzeba je skoncentrować na adaptacji rozumianej zwykle jako likwidacja skutków ekstremalnych wydarzeń (czyli w ujęciu nieuwzględniającym przygotowywania do ewentualnych skutków przyszłych zdarzeń).

Pojawia się jednak pytanie, dlaczego ci, którzy nie wierzą w zmiany klimatyczne spowodowane przez człowieka, są w ogóle skłonni przeznaczać jakiekolwiek środki na działania o charakterze zapobiegania czy też łagodzenia tych zmian? Na podstawie materiałów jakościowych zebranych w trakcie badań terenowych sądzimy, że wiąże się to z dostępnością różnego rodzaju dotacji (przede wszystkim w nowej perspektywie finansowej Unii Europejskiej) na podejmowanie takich działań. Skoro fundusze są dostępne, to należy o nie występować, przeprowadzając inwestycje związane np. z termomodernizacją czy modernizacją systemów ogrzewania w miastach. Można się przy tym posłużyć frazeologią ograniczania wpływu na klimat (skoro posłużenie się nią zwiększa szansę na uzyskanie środków), ale prawdziwymi motywami podejmowania tych działań są chęć oszczędności związanych ze zmniejszeniem zużycia energii czy też poprawa jakości powietrza w naszym mieście. Nie mówiąc już o tym, że wysoka pozycja w wykorzystaniu funduszy unijnych (bez względu na cel i sposób ich wydawania) jest zawsze opłacalna politycznie dla władz samorządowych.

Wyniki pokazane w tab. 4 i 5 potwierdzają też wyniki testu modelu regresji, w której zmienną zależną jest skłonność do przeznaczania środków na łagodzenie zmian klimatu, a zmiennymi niezależnymi są zmienne uwzględnione w badaniu związków korelacyjnych. Jedynymi istotnymi zmiennymi wyjaśniającymi w tym modelu okazują się wiara we wpływ człowieka na zmiany klimatu oraz przekonanie, że działania związane z ograniczaniem tego wpływu należy podjąć natychmiast, nawet jeśli pociąga to za sobą znaczne koszty (tab. 6).

Okazuje się w szczególności, że zaobserwowana we wcześniej opisanych związkach korelacyjnych zależność od poparcia dla niektórych partii politycznych ma charakter wtórny wobec przekonania respondentów o istnieniu i istotności globalnych zmian klimatycznych. 
Tab. 5. Część środków przeznaczanych na adaptację i łagodzenie w zależności od odpowiedzi na wybrane pytania

Table 5. Percentage of means dedicated to adaptation and mitigation activities after responses to selected questions

\begin{tabular}{|c|c|}
\hline $\begin{array}{c}\text { \% środków przeznaczanych } \\
\text { na adaptację } \\
\% \text { of means devoted to } \\
\text { adaptation }\end{array}$ & $\begin{array}{c}\text { \% środków } \\
\text { przeznaczanych } \\
\text { na łagodzenie } \\
\% \text { of means devoted } \\
\text { to mitigation }\end{array}$ \\
\hline
\end{tabular}

\begin{tabular}{|c|c|c|}
\hline \multicolumn{3}{|c|}{$\begin{array}{l}\text { W jakim stopniu przekonują Pana (Panią) dowody, że za zmiany klimatyczne odpowiada człowiek } \\
\text { To what extent are you convinced by the proofs saying that people is responsible for climate change }\end{array}$} \\
\hline $\begin{array}{l}\text { Dowody są przekonujące, nie mam wątpliwości } \\
\text { Poofs are convincing, I have no doubts }\end{array}$ & 42,6 & 57,4 \\
\hline $\begin{array}{l}\text { Dowody są raczej przekonujące, ale mam wątpliwości } \\
\text { Proofs are quite convincing, but I still have some doubts }\end{array}$ & 45,3 & 54,7 \\
\hline $\begin{array}{l}\text { Nie ma przekonujących dowodów na wpływ człowieka } \\
\text { There is no convincing proof confirming human impact }\end{array}$ & 55,3 & 44,7 \\
\hline $\begin{array}{l}\text { Nie jestem przekonany, że klimat się zmienia } \\
\text { I am not convinced that climate is changing }\end{array}$ & 47,1 & 52,9 \\
\hline \multicolumn{3}{|c|}{$\begin{array}{l}\text { Które ze stwierdzeń jest najbliższe Pana (Pani) poglądom } \\
\text { Which opinion is closer to your views? }\end{array}$} \\
\hline $\begin{array}{l}\text { Zmiany klimatu to pilny problem. Działania trzeba podejmować } \\
\text { natychmiast nawet jeśli wiążą się ze znacznymi kosztami } \\
\text { Climate chance is an urgent problem. Action should be undertaken } \\
\text { immediately, even if they involve high costs. }\end{array}$ & 42,1 & 57,9 \\
\hline $\begin{array}{l}\text { Zmianami klimatu trzeba się zajęć, ale środki zaradcze należy } \\
\text { wprowadzać stopniowo, aby ograniczać koszty } \\
\text { Climate changes have to be delt with, but it should be done } \\
\text { step by step to limit the costs. }\end{array}$ & 45,0 & 55,0 \\
\hline $\begin{array}{l}\text { Dopóki nie jesteśmy pewni, że zmiany klimatu są rzeczywiście } \\
\text { problemem, nie należy podejmować kroków pociągających koszty } \\
\text { As long as we are not sure if climate change is a problem, no costy } \\
\text { action should be taken. }\end{array}$ & 60,8 & 39,2 \\
\hline \multicolumn{3}{|c|}{$\begin{array}{c}\text { Czy Pana (Pani) zdaniem zwiększona częstotliwość ekstremalnych zjawisk pogodowych wiąże się } \\
\text { z globalnymi zmianami klimatycznymi? } \\
\text { In your mind, is an increased frequency of extreme weather events related to global climate changes? }\end{array}$} \\
\hline $\begin{array}{l}\text { Tak } \\
\text { Yes }\end{array}$ & 42,1 & 57,9 \\
\hline $\begin{array}{l}\text { Tak, częściowo } \\
\text { Yes, partly }\end{array}$ & 45,0 & 55,0 \\
\hline $\begin{array}{l}\text { Praktycznie w ogóle } \\
\text { No }\end{array}$ & 60,8 & 39,2 \\
\hline \multicolumn{3}{|c|}{$\begin{array}{l}\text { Władze lokalne powinny podejmować działania w zakresie przeciwdziałania zmianom klimatu } \\
\text { Local authorities should undertake action to prevent climate changes }\end{array}$} \\
\hline $\begin{array}{l}\text { Tak } \\
\text { Yes }\end{array}$ & 45,2 & 54,8 \\
\hline $\begin{array}{l}\text { Nie } \\
\text { No }\end{array}$ & 48,4 & 51,6 \\
\hline
\end{tabular}


Tab. 6. Czynniki wyjaśniające skłonność preferencji do łagodzenia zmian klimatu w wyborze celów polityki klimatycznej - model regresji

Table 6. Factors explaining preference to Focus on mitigation in local climate policy - regression model

\begin{tabular}{|c|c|c|}
\hline R & \multicolumn{2}{|c|}{0,368} \\
\hline R square & \multicolumn{2}{|c|}{0,135} \\
\hline $\begin{array}{l}\text { Zmienne wyjaśniające } \\
\text { Explanatory variables }\end{array}$ & Beta & $\begin{array}{c}\text { Istotność } \\
\text { (significance) }\end{array}$ \\
\hline $\begin{array}{l}\text { Postrzegana podatność na wszelkie ekstremalne zjawiska pogodowe } \\
\text { Perceived vulnerability to extreme weather events }\end{array}$ & $-0,034$ & 0,211 \\
\hline $\begin{array}{l}\text { Ekstremalne zjawiska pogodowe w gminie spowodowane są globalnymi } \\
\text { zmianami klimatycznymi } \\
\text { Extreme weather evets in a commune are caused by global climate changes }\end{array}$ & 0,082 & 0,052 \\
\hline $\begin{array}{l}\text { Dowody na wpływ człowieka na zmiany klimatyczne są przekonujące } \\
\text { Proofs of human influence on climate change are convincing }\end{array}$ & 0,198 & 0,000 \\
\hline $\begin{array}{l}\text { Zmiany klimatu to poważny i pilny problem, trzeba podjąć działania } \\
\text { nawet jeśli wiąże się to ze znacznymi kosztami } \\
\text { Climate change is an important and urgent problem, it should be delt } \\
\text { with even at high costs }\end{array}$ & 0,179 & 0,000 \\
\hline $\begin{array}{l}\text { Władze lokalne powinny podejmować działania związane ze zmianami } \\
\text { klimatycznymi } \\
\text { Local authorities should undertake actions related to climate change }\end{array}$ & 0,005 & 0,903 \\
\hline $\begin{array}{l}\text { Wykształcenie respondenta } \\
\text { Respondent's education }\end{array}$ & $-0,040$ & 0,271 \\
\hline $\begin{array}{l}\text { \% głosów na PiS w wyborach } 2015 \\
\% \text { of votes for PiS in elections } 2015\end{array}$ & $-0,004$ & 0,957 \\
\hline $\begin{array}{l}\text { \% głosów na PO w wyborach } 2015 \\
\% \text { of votes for PO in elections } 2015\end{array}$ & 0,014 & 0,832 \\
\hline $\begin{array}{l}\text { \% głosów na ZLew w wyborach } 2015 \\
\% \text { of votes for ZLew in elections } 2015\end{array}$ & 0.039 & 0,396 \\
\hline $\begin{array}{l}\text { Zamożność gminy } \\
\text { Commune wealth }\end{array}$ & 0,017 & 0,647 \\
\hline $\begin{array}{l}\text { Liczba ludności gminy (In) } \\
\text { Population size (In) }\end{array}$ & $-0,022$ & 0,577 \\
\hline
\end{tabular}




\section{Podsumowanie}

Badanie wykazało dość dużą zbieżność sytuacji w polskich samorządach lokalnych z opisywaną w literaturze zagranicznej. Wśród deklarowanych przez polskie gminy działań przeważają polityki łagodzące zmiany klimatu, co ma związek z ogólnopolskim i unijnym wsparciem. Wytyczne dotyczące realizacji na poziomie lokalnym gospodarki niskoemisyjnej w połączeniu ze źródłami dofinansowania inwestycji z tego zakresu zaowocowały wyraźnym skupieniem samorządów na ochronie powietrza.

Badając potencjalne przyczyny zróżnicowania działań wobec zmian klimatu, zauważyliśmy, że główną zmienną determinującą jest wielkość gminy (mierzona liczbą mieszkańców; potwierdzona H3), co tłumaczymy związkiem z jej zasobami (np. kompetencjami pracowników administracyjnych, które wpływają na możliwość specjalizacji). Zgodnie z przewidywaniami w przypadku działań adaptacyjnych ważne jest także postrzegane zagrożenie ekstremalnymi zjawiskami pogodowymi związanymi ze środowiskiem wodnym (potwierdzona H1). Pozostałe zmienne mają charakter wtórny wobec wielkości (H2 i H5 niepotwierdzona).

$Z$ kolei deklarowanie chęci wydawania większych pieniędzy na łagodzenie niż na adaptację wiąże się wyraźnie z wiarą we wpływ człowieka na zmiany klimatu oraz przekonaniem, że samorząd powinien prowadzić politykę klimatyczną (potwierdzona H4).

Warto podkreślić, że z naszych badań wynika, iż także zamożność nie jest istotną zmienną wyjaśniającą podejmowane polityki klimatyczne. To nie zamożność decyduje, że coś robimy lub nie, choć może decydować o skali działań. Decydująca jest świadomość (wiara) i umiejętności oraz kompetencje wiążące się z wielkością jednostki samorządowej.

\section{Literatura}

Baró F., Chaparro L., Gómez-Baggethun E., Langemeyer J., Nowak D.J., Terrades J., 2014, Contribution of ecosystem services to air quality and climate change mitigation policies: The case of urban forests in Barcelona, Spain, AMBIO 43, 466-479.

Berkhout F., Hertin J., Gann D.M., 2006, Learning to Adapt: Organisational adaptation to climate change impacts climatic change, 78 (1), 135-156.

Betsill M.M, Bulkeley H , 2007, Looking back and thinking ahead: A decade of cities and climate change research, Local Environment, 12 (5), 447-456.

Bulkeley H., Betsill M.M., 2003, Cities and climate change: Urban sustainability and global environmental governance, Routledge, London.

Bulkeley H., Kern K., 2006, Local government and the governing of climate change in Germany and the UK, Urban Studies, 43 (12), 2237-2259. 
Bulkeley H., Tuts R., 2013, Understanding urban vulnerability, adaptation and resilience in the context of climate change, Local Environment, 18 (6), 646-662.

Collier U., 1997, Local authorities and climate protection in the European union: Putting subsidiarity into practice?, Local Environment, 2 (1), 39-57.

Erdik M., Durukal E., 2008, Earthquake risk and its mitigation in Istanbul, Natural Hazards, 44, 181-197.

Gustavsson E., Elander I., 2012, Cocky and climate smart? Climate change mitigation and place-branding in three Swedish Towns, Local Environment, 17 (1), 1-12.

Granberg M., Elander I., 2007, Local governance and climate change: Reflections on the Swedish experience, Local Environment, 12 (5), 537-548.

Granberg M., Glover L., 2012, Climate change adaptation policy and practice: The Swedish experience, Paper presented at the annual XXI Nordic Municipal Research Conference (NORKOM), Oslo University, Norway, 22-24 of November, 2012.

Hamin E.M., Gurran N., 2008, Urban form and climate change: Balancing adaptation and mitigation in the U.S. and Australia, Habitat International, 1-8.

Hanssen S.G., Mydske P.K., Dahle E., 2012, Multi-level coordination of climate change adaptation: By national hierarchical steering or by regional network governance?, Local Environment, 18 (8), 869-887.

Hoppe T., Coenen F., 2011, Creating an analytical framework for local sustainability performance: A dutch case study, Local Environment, 16 (3), 229-250.

Hoppe T., Berg M. van den, Coenen F., 2014, Reflections on the uptake of climate change policies by local governments: Facing the challenges of mitigation and adaptation, Energy, Sustainability and Society, 4 (8), 1-16.

Hovik S., Naustdalslid J., Reitan M., Muthanna T., 2011, Adaptation to climate change in the water sector in Norway - local capabilities for proactive strategies in a changing institutional framework, Tekst prezentowany podczas corocznej konferencji ECPR w 2011 roku.

Jackson T., Lynch W., 2011, Public sector responses to climate change: Evaluating the role of Scottish local government in implementing the climate change (Scotland) Act 2009, Research and Evaluation Commonwealth Journal of Local Governance, 8/9, http://epress.lib.uts.edu.au/ojs/ index.php/cjlg (20.02.2017).

Kaniasty K., 2003, Klęska żywiotowa czy katastrofa spoteczna? Psychologiczne konsekwencje polskiej powodzi 1997 roku, Gdańskie Wydawnictwo Psychologiczne, Gdańsk.

Koll C.K., Schophaus M., 2004, Local Agenda 21 in Germany: An inter-and intranational comparison: Discussion paper, Wissenschaftszentrum Berlin für Sozialforschung, Berlin.

Krajowy Program Ochrony Powietrza do roku 2020, 2015, Warszawa, https:/www.mos.gov.pl/ fileadmin/user_upload/mos/srodowisko/lesnictwo/KPOP_do_roku_2020.pdf (6.10.2016).

Kundzewicz Z.W., 2009, Klęski šywiotowe - obserwacje, projekcje i mo:i liwości prweciwdæiałania, [w:] M. Gutry-Korycka, T. Markowski (red.), Zrównoważone warunki życia w zmieniajqcym się systemie klimatycznym Ziemi, Polska Akademia Nauk, Studia Komitetu Przestrzennego Zagospodarowania Kraju PAN, Warszawa, 22-39. 
Kundzewicz Z.W., Matczak P., 2012, Natural risks: Mitigation and adaptation, Ecohydrology \& Hydrobiology, 12 (1), 3-8.

Matczak P., 2008, Adaptacja do zmian klimatu, KOSMOS. Problemy Nauk Biologicznych, 57 (3-4), 281-292.

Misja: emisja, http://misja-emisja.pl/knowledgebase/plany-gospodarki-niskoemisyjnej -cele-zadania/ (24.08.2016).

Orderud G.I., Winsvold M., 2012, The role of learning and knowledge in adapting to climate change: A case study of Norwegian municipalities, International Journal of Environmental Studies, 69 (6), 946-961.

Otto-Banaszak I., Matczak P., Wesseler J., Wechsung F., 2011, Different perceptions of adaptation to climate change: A mental model approach applied to the evidence from expert interviews, Regional Environmental Change, 11 (2), 217-228.

Podręczik adaptacji dla miast. Wytyczne do przygotowania Miejskiego Planu Adaptacji do smian klimatu, 2015, Ministerstwo Środowiska, Warszawa.

Raport o stanie przygotowań lokalnych do zmian klimatu. Dobry klimat dla powiatów, 2012, Instytut na Rzecz Ekorozwoju, Warszawa.

Shaw K. Theobald K. (2011), Resilient local government and climate change interventions in the UK, Local Environment, 16 (1), 1-15.

Smit B., Wandel J., 2006, Adaptation, adaptive capacity and vulnerability, Global Environmental Change, 16, 282-292.

Storbjörk S., 2007, Governing climate adaptation in the local arena: Challenges of risk management and planning in Sweden, Local Enviroment, 12 (5), 457-469.

Swyngedouw E., 2004, Globalisation or 'Glocalisation'? Networks, Territories and Rescaling, Cambridge Review of International Affairs, 17 (1), 25-48.

Swianiewicz P., Łukomska J., 2014, Niełatwo być bogatym w chudych latach, Wspólnota, 13, 44-49. Verchot L.V., Van Noordwijk M., Serigne K., Tomich T., Ong C., Albrecht A., Mackensen J., Bantilan C., Anupama K.V., Palm C., 2007, Climate change: Linking adaptation and mitigation through agroforestry, Mitigation and Adaptation Strategies for Global Change, 12 (5), 901-918.

Winsvold M., Stokke K.B., Klausen J.E., Saglie I.L., 2009, Organizational learning and governance in adaptation i urban development, [w:] W.N. Adger, I. Lorenzoni, K. O’Brien (red.), Adapting to climate change: Thresholds, values, governance, Cambridge University Press, Cambridge, 476-490.

Zahran S., Brody S., Vedlitz A., Grover H., Miller C., 2008, Vulnerability and capacity: Explaining local commitment to climate-change policy, Environment and Planning C: Govern ment Policy, 26 (3), 544-562.

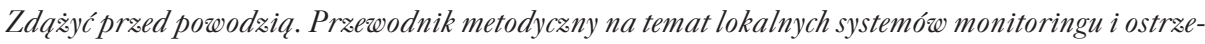
¿̇eń powodziowych, 2005, Instytut Meteorologii i Gospodarki Wodnej (IMGW), Kraków. 


\section{Źródła internetowe}

http://www.stefczyk.info/publicystyka/opinie/szyszko-globalne-ocieplenie-bylo-decyzjapolityczna, $9085670552(20.02 .2017)$.

http://naukaoklimacie.pl/fakty-i-mity/mit-zmiana-klimatu-to-nie-problem-bo-tak-twierdziswiatowa-federacja-naukowcow-115 (20.02.2017).

http://korwin-mikke.pl/szukaj/tag/klimat (20.02.2017).

Marta Lackowska

Uniwersytet Warswawski

Wydziat Geografii i Studiów Regionalnych

ul. Krakowskie Przedmieście 26/28, 00-927 Warszawa

m.lackowska@uw.edu.pl

Pawet Swianiewic:

Uniwersytet Warswawski

Wydziat Geografii i Studiów Regionalnych

ul. Krakowskie Przedmiescie 26/28, 00-927 Warsæawa

pswian@uw.edu.pl 